\title{
Riparian ecotones and spatial variation of fish assemblages in Portuguese lowland streams
}

\author{
M. J. Collares-Pereira, M. F. Magalhāes, A. M. Geraldes \& M. M. Coelho \\ Departamento de Zoologia e Antropologia, Faculdade de Ciências, Campo Grande, Bloco C2, 3o Piso, \\ 1700 Lisboa, Portugal
}

Key words: riparian ecotones, fish assemblages, spatial variation, Iberian streams

\begin{abstract}
The first results of a long-term study on the role of riparian ecotones on the population and community dynamics of Iberian stream fish are presented and discussed. Riparian and macrophyte cover, bank slope and depth were among the most important variables affecting fish distribution. In general small fish favoured shallow areas with high macrophyte cover, whereas large fish dominated in deep areas with a high riparian cover. Slight spatial changes in terrestrial prey use were found suggesting a minor role for this resource during autumn. Finally, no significant spatial differences were found for linear growth, although some differences were obtained for the condition factor.
\end{abstract}

\section{Introduction}

Studies of stream fish assemblages have shown that abiotic factors such as temperature, current velocity, depth and substratum, can determine the distribution and abundance of individual species as well as influence community-level properties such as species diversity, guild-composition and production (Rahel \& Hubert, 1991).

In recent years it has been progressively emphasized that the population and community dynamics of stream fish may also greatly depend on the structure and complexity of riparian zones (Zalewski, 1990, 1991; Schiemer \& Zalewski, 1992). In fact, the aquatic-terrestrial interface is a critical area on the landscape, combining spatial heterogeneity, availability of refugia from harsh environmental conditions and from predators, and a large supply of nutrients and organic matter, including terrestrial invertebrates (Schlosser, 1991).
Southern streams of the Iberian Peninsula have marked seasonal variations from occasional floods to extensive droughts, which may enhance the importance of riparian habitats. If so, management options for the conservation/restoration of riparian ecotones should be urgently defined before human influences will irreversibly affect fish assemblages, particularly the endemic cyprinid fauna.

In the Sorraia system (the largest left tributary of the R. Tejo), some zones are under a strong human pressure (sand/silt and water extraction, river bed and banks linearization, eutrophication and chemical pollution, dam construction), whereas others are still under a low level of disturbance. Thus this system was considered suitable to further analyse the buffer role played by riparian zones in regulating the spatial and temporal dynamics of fish populations and communities. Besides, base line studies on the spatial and temporal structure of aquatic and riparian 
vegetation were already available for this hydrographic system (Ferreira \& Moreira, 1987; Ferreira, 1992).

Included in a long-term study, some data are now presented focusing on the spatial variation of (1) the distribution and size-structure of individual species as well as of fish assemblage composition, (2) the patterns of terrestrial prey use by non-benthic fish, and (3) the growth and condition of fish.

\section{Study area}

The 12 surveyed sites listed in Fig. 1, belong to the Sor stream (sites A and B) and to the Sorraia river ( order streams, and are characterised by a mosaic of habitat conditions and highly diversified biocenosis. Banks have a moist deep soil layer allowing the occurrence of dense riparian formations. Sand is the dominant substratum, although in Sor upper reaches calco-alkaline granite deposits may be found.

In the Sorraia R., the three zones defined by Ferreira (1992) for the alluvial corridor Sta JustaCoruche, were sampled:
Zone I - 'semi-natural' zone $(7.5 \mathrm{~km})$, partiallyregularized, owing to the existence of river bed and banks linearization (constant apparent river bed $60-65 \mathrm{~m}$ ), with regular wall-barriers and agricultural discharges; the river bed is regular, only rarely with wet sand flats; the relative surface of the distinct habitats and associate vegetation are very constant. Dominant trees are the willows (Salix alba spp. vitelina, Salix salvifolia spp. salvifolia), and the water and bank herbaceous dominants are Erodium moschatum, Cynodon dactylon, Poa annua, Phragmites australis and Arundo donax (site C).

Zone II - the most 'natural' zone $(12.5 \mathrm{~km})$, in which the apparent river bed width is highly variable (from 40 to $100 \mathrm{~m}$ ) and the human influence is much less marked; river water branches and ondulates through wet sand flats creating open river areas, with distinct depths. Dominant trees are willows, poplars (Populus nigra) and ashe trees (Fraxinus angustifolia) (some of these trees grow down to the water level), and the major water and bank herbaceous are Potamogetom fluitans, Myriophyllum aquaticum, $M$. spicatum and Ceratophyllum demersum (sites D to L).
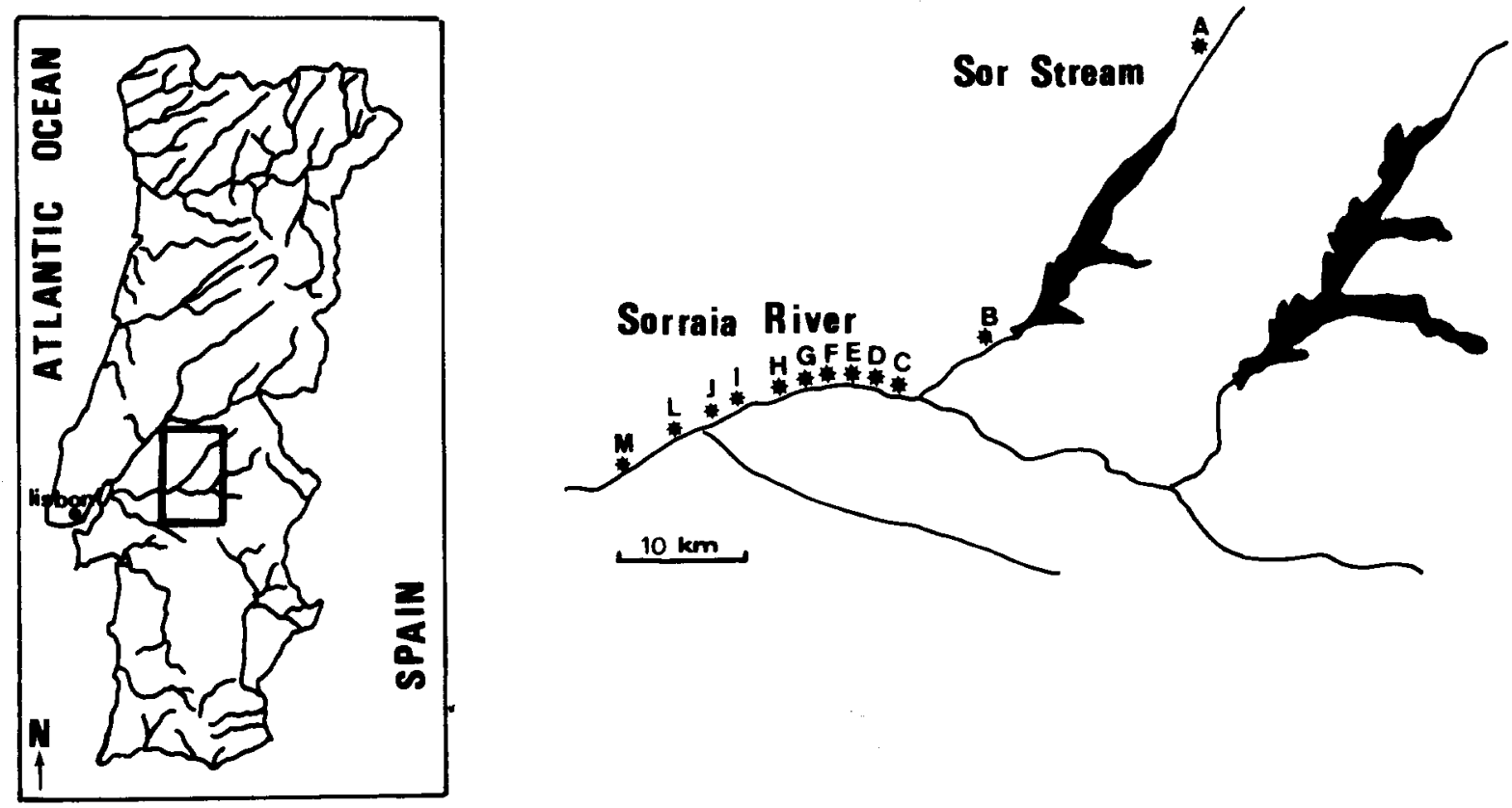

Fig. 1. Study sites along the Sorraia system, the main left tributary of Tagus river in Portugal. 
Zone III - the most 'artificial' zone $(2.5 \mathrm{~km})$, annually regularised and prepared for fish game competition with the use of flood-gates, river bed and banks linearization and with willows and helophytic vegetation control. There are no sand habitats and the riparian zone is relatively reduced, presenting almost exclusively willows as lotic vegetation cover and a patchy distribution of Myriophyllum aquaticum (site M).

Two sites in the Sor stream were also included because a previous analysis (Magalhaes et al., 1991) suggested distinct spatial patterns for the distribution of the dominant cyprinid species in the R. Sorraia and its tributaries. A sand substratum predominates in the study sites isolated since 1958 by the Montargil reservoir. Below the reservoir (site B) the typical water and bank herbaceous species are Mentha aquatica, Licopus, europeus, Juncus articulatus and Myriophyllum aquaticum, and above (site A) species like Paspallum paspalodes, Frimbristillis bisumbellata, Lotus pedunculatum and Illecebrum verticillatum dominate (Ferreira \& Moreira, 1987). Willows, poplars and alders (Alnus glutinosa) not found in site B are dominant trees in site A.

The Sorraia system has a rich-species fish community, clearly dominated by the family Cyprinidae (Table 1). The most abundant taxa are the endemic roach 'Rutilus alburnoides complex', the Iberian barbel Barbus bocagei and the endemic chub Leuciscus pyrenaicus.

The roach represents an important fraction of the fish community and constitutes a wellestablished diploid-triploid complex of forms involved in bisexual-unisexual modes of reproduction, but it is still waiting for more reliable morphological and genetic characterisations (see Collares-Pereira, 1989). The second species is the barbel, which has a quite distinct migratory behaviour, at least during the reproductive period (Rustarazo et al., 1989).

Table 1. Fish fauna of R. Sorraia system. First figure = number of fish captured; figure in parenthesis $=\%$ number of captures.

\begin{tabular}{|c|c|c|}
\hline Family & Species & Number \\
\hline \multirow[t]{9}{*}{ Cyprinidae } & - Rutilus alburnoides complex (Steindachner, 1866) & $2298(57.88)$ \\
\hline & Barbus bocagei Steindachner, 1865 & $1184(29.82)$ \\
\hline & Leuciscus pyrenaicus (Gunther, 1868) & $185(4.66)$ \\
\hline & Chondrostoma polylepis Steindachner, 1865 & $156(3.93)$ \\
\hline & Gobio gobio (Linnaeus, 1758) & $22(0.55)$ \\
\hline & Cyprinus carpio Linnaeus, 1758 & $18(0.45)$ \\
\hline & Carassius auratus (Linnaeus, 1758) & $18(0.45)$ \\
\hline & Chondrostoma lusitanicum Collares-Pereira, 1980 & $26(0.66)$ \\
\hline & Barbus comiza Steindachner, 1865 & $1(0.03)$ \\
\hline Cobitidae & - Cobitis maroccana Pellegrin, 1921 & $54(1.36)$ \\
\hline \multirow[t]{2}{*}{ Centrarchidae } & - Lepomis gibbosus (Linnaeus, 1758) & $1(0.03)$ \\
\hline & Micropterus salmoides Lacépède, 1802 & - \\
\hline Poeciliidae & - Gambusia holbrooki Girard, 1859 & $3(0.07)$ \\
\hline \multirow[t]{2}{*}{ Petromyzontidae } & - Lampetra fluviatilis (Linnaeus, 1758) & - \\
\hline & Petromyzon marinus Linnaeus, 1758 & - \\
\hline Anguillidae & - Anguilla anguilla (Linnaeus, 1758) & $2(0.05)$ \\
\hline Mugilidae & - Liza ramada (Rizzo, 1826) & $2(0.05)$ \\
\hline Atherinidae & - Atherina boyeri Risso, 1810 & - \\
\hline
\end{tabular}




\section{Material and methods}

\section{Fish assemblages and environmental variables}

Altogether eleven sites, each 50-70 m long, were selected (sites $B$ to $M$ ). The number and length of sites were chosen to represent the range of habitats and plant communities occurring in both streams and all sites were sampled in October 1991.

Fishes were captured by electrofishing along both banks, identified, measured for total and standard length (to within $1 \mathrm{~mm}$ ) and weight (to within $0.01 \mathrm{~g}$ ).

Eleven environmental variables were measured for each sampling date and site:(1) channel width (m); (2) water depth (m); (3) current velocity $\left(\mathrm{m} \mathrm{s}^{-1}\right)$; (4) temperature $\left({ }^{\circ} \mathrm{C}\right)$; (5) conductivity $(\mu \mathrm{S})$; (6) oxygen $\left(\mathrm{mg} \mathrm{l}^{-1}\right)$, (7) dominant substratum; (8) bank slope; (9) macrophytes cover; (10) riparian cover (bushes and/or trees); (11) percent covered by canopy. Variables 7 to 10 were measured using qualitative categories: 7) substratum - (1) organic cover; (2) silty sand $(1-2 \mathrm{~mm})$; (3) sand $(2-5 \mathrm{~mm})$; (4) gravel (5$25 \mathrm{~mm})$; (5) pebble $(25-50 \mathrm{~mm})$; (6) rock $(50-$ $100 \mathrm{~mm}$ ); (7) cobble (100-250 mm); (8) boulder $(>250 \mathrm{~mm}) ; 8)$ bank slope - (1) very steep; (2) steep; (3) gentle slope; (4) convex slope; 9) and 10) macrophytes and riparian cover - (1) absent; (2) light presence; (2) median presence; (3) dense; (4) very dense.

Sampling protocol for variables 1 to 7 followed Gorman \& Karr (1978) with slight modifications. Beginning $10-20 \mathrm{~cm}$ from the banks, point samples were taken at four meters intervals along the stream. Repeated sets of points were taken across the stream at ten meters intervals, moving upstream. Variables 8 to 10 were measured at five to seven points taken along each bank at ten meter intervals. Habitat volume $\left(\mathrm{m}^{3}\right)$ and habitat area $\left(\mathrm{m}^{2}\right)$ for each sampling site were calculated according to Schlosser (1987).

To detect patterns in fish assemblages and to relate these patterns to environmental factors, the general procedure recommended by Green \& Vascotto (1978) was used. Fish assemblage patterns were identified using cluster analysis (Pearson correlation coefficient, UPGMA) for all the species individually, except those with a percentage occurrence lower than $0.1 \%$, were pooled together. A Kruskall-Wallis test was carried out for each environmental variable in order to determine whether the species assemblage clusters differed significantly from each other in their median value of that variable.

\section{Terrestrial prey utilization}

Previous studies on the cyprinid diets and patterns of food resource partitioning in the Sorraia system (Magalhāes \& Collares-Pereira, 1991; Magalhāes, 1992; 1993), suggested that terrestrial invertebrates were minor components of the diet of benthic-cyprinids over all the year but they were major components of the roach and chub diets during the dry season.

So, in the present analysis, roach and chub were sampled at sites $\mathrm{B}, \mathrm{C}, \mathrm{E}$ and $\mathrm{M}$. Whenever available, twenty fish of each species, spanning the entire size range in the collection, were selected. These fish were placed in an ice-bath, and deep frozen within three to six hours.

The entire gut contents were analysed, and the percentage occurrence of plant material and the numerical percentage of animal prey, were determined. Percentage occurrence was calculated omitting empty guts and numerical percentage was based on total numbers of prey in a sample (Hyslop, 1980).

Overlaps in animal prey use were computed using the Schoener formula and were regarded as high when values exceeded 0.6 (Wallace, 1981). To assess the importance of terrestrial prey in relation to species interactions, animal prey overlaps were calculated considering only the aquatic prey and then both aquatic and terrestrial prey. Prey were considered terrestrial if they were the result of terrestrial secondary production, not aerial adults of aquatic forms (sensu Garman, 1991). 


\section{Linear growth and condition}

For the linear growth and condition analyses, the chub was the species selected first. Fish were captured at sites $\mathrm{A}, \mathrm{B}, \mathrm{C}, \mathrm{E}$ and $\mathrm{M}$, measured for standard lengths and four to six scales were removed. Condition factor was calculated over fish total length and linear growth over fish standard length. Back-calculations were performed by the SPH (Scale Proportional Hypothesis) method (in Francis, 1990). One-way analysis of variance (ANOVA) and the Kruskall-Wallis test were used to test for spatial variations on the back-calculated length and condition factor of fish, respectively.

\section{Results}

Of the 18 species reported for the Sorraia system, only 14 species were collected in this study (Table 1). Among the 3970 fish sampled, the most common species were the roach $(57.9 \%)$ and the barbel $(29.8 \%)$. The other species captured were much less represented and those with a numerical percentage less than $0.1 \%$ were jointly considered for the cluster analysis of relative abundance data matrix.

Fish relative abundances clustered into three assemblage groups (Fig. 2). In the first group (sites B, C, and M), fish assemblages were dominated by roach. Sites in the second group (D, E, $F$ and I) presented an equal proportion of roach and barbel. In the third group (sites $\mathrm{G}, \mathrm{H}, \mathrm{J}$ and L) the barbel was the predominant species.

Means for the environmental variables grouped according to fish assemblage type (1, 2 or 3 ) were positioned along an environmental gradient. Variables describing width, depth, oxygen, riparian cover and substratum were significantly different among groups (Table 2). Sites dominated by roach (group 1) were narrow and shallow, presented the lowest oxygen concentration and riparian cover and the most coarse substratum. Sites dominated by barbel (group 3) were deepest, more oxygenated and presented a smooth substratum. Sites with both species (group 2) were wider and presented more riparian cover.

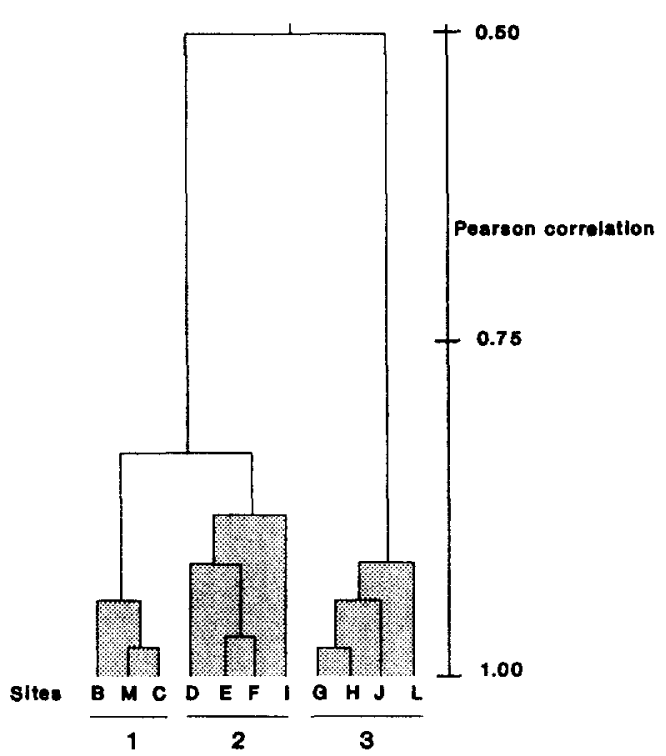

Fig. 2. Similarity of fish assemblages in the sampling sites. Dendogram showing three groups based on cluster analysis of relative fish number data (UPGMA method, cophenetic correlation 0.870 ). Sampling site codes as in Fig. 1.

A preliminary insight into the spatial variation of fish populations structure was obtained by comparing the size-compositions of roach, barbel and chub from the sampling sites where the species were abundant (Fig. 3). Length-frequency

Table 2. Means of the 12 environmental variables calculated for clusters of sampling sites. Results of Kruskall-Wallis test are also presented. ${ }^{*} p<0.05 ;^{* *} p<0.01$. Cluster codes as in Fig. 2.

\begin{tabular}{lrrrc}
\hline Variables & \multicolumn{3}{l}{ Sampling site clusters } & \multirow{2}{*}{ H } \\
\cline { 2 - 4 } & \multicolumn{1}{c}{2} & \multicolumn{2}{c}{3} \\
& \multicolumn{1}{c}{2} & & \\
\hline Width (m) & 8.7 & 25.9 & 17.6 & $21.9^{* *}$ \\
Depth (m) & 0.3 & 0.4 & 0.5 & $29.5^{* *}$ \\
Current (ms ${ }^{-1}$ ) & 14.8 & 12.2 & 12.0 & 4.0 \\
Temperature $\left({ }^{\circ} \mathrm{C}\right)$ & 17.1 & 17.6 & 17.5 & 6.2 \\
Conductivity $(\mu \mathrm{S})$ & 337.2 & 341.5 & 344.5 & 5.4 \\
Oxygen (mg 1 ${ }^{-1}$ ) & 7.1 & 7.8 & 8.0 & $11.5^{* *}$ \\
Substratum & 3.4 & 3.1 & 3.0 & $7.5^{*}$ \\
Bank slope & 2.5 & 2.6 & 2.7 & 2.6 \\
Macrophytes & 1.6 & 2.3 & 1.9 & 0.7 \\
Riparian cover & 0.3 & 1.6 & 0.8 & $6.0^{*}$ \\
Canopy (\%) & 5.0 & 8.3 & 8.4 & 3.2 \\
Volume & 243.7 & 451.8 & 472.6 & 3.4 \\
\hline
\end{tabular}



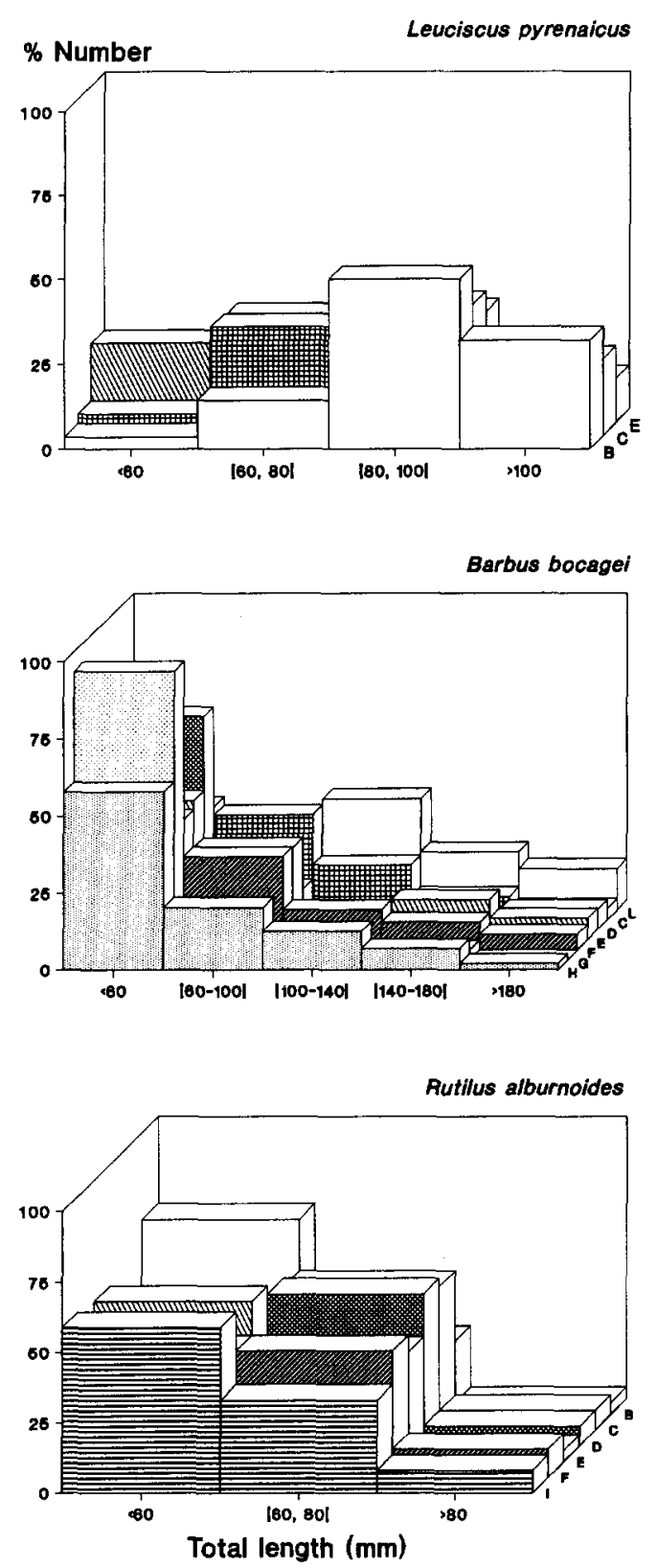

Fig. 3. Spatial changes in length-frequency distribution of roach, barbel and chub. Sampling site codes as in Fig. 1.

distributions of roach and chub were similar among all sampling sites. Most roach were $<80 \mathrm{~mm}$, whereas most chub were between 60 and $100 \mathrm{~mm}$. Most barbel were less than $100 \mathrm{~mm}$ at all sites, except site $\mathrm{L}$, where most specimens were between 100 and $140 \mathrm{~mm}$ and the highest oxygen values were observed $\left(9.2 \mathrm{mg} \mathrm{l}^{-1}\right.$ versus
$6.5-7.7 \mathrm{mg}^{-1}$. The low frequency of small fish at site $\mathrm{L}$ is probably related to the high current velocity $\left(22.6 \mathrm{~m} \mathrm{~s}^{-1}\right.$ versus $6.5-15.8 \mathrm{~m} \mathrm{~s}^{-1}$ in the remaining sites). Figure 4, shows the percentage captures for the different size-classes of roach, barbel and chub along the river banks at site $\mathrm{E}$. Significant differences between river banks were found for depth $(H=5.769, p<0.05)$, macrophytes $(H=5.771, p<0.05)$, riparian cover
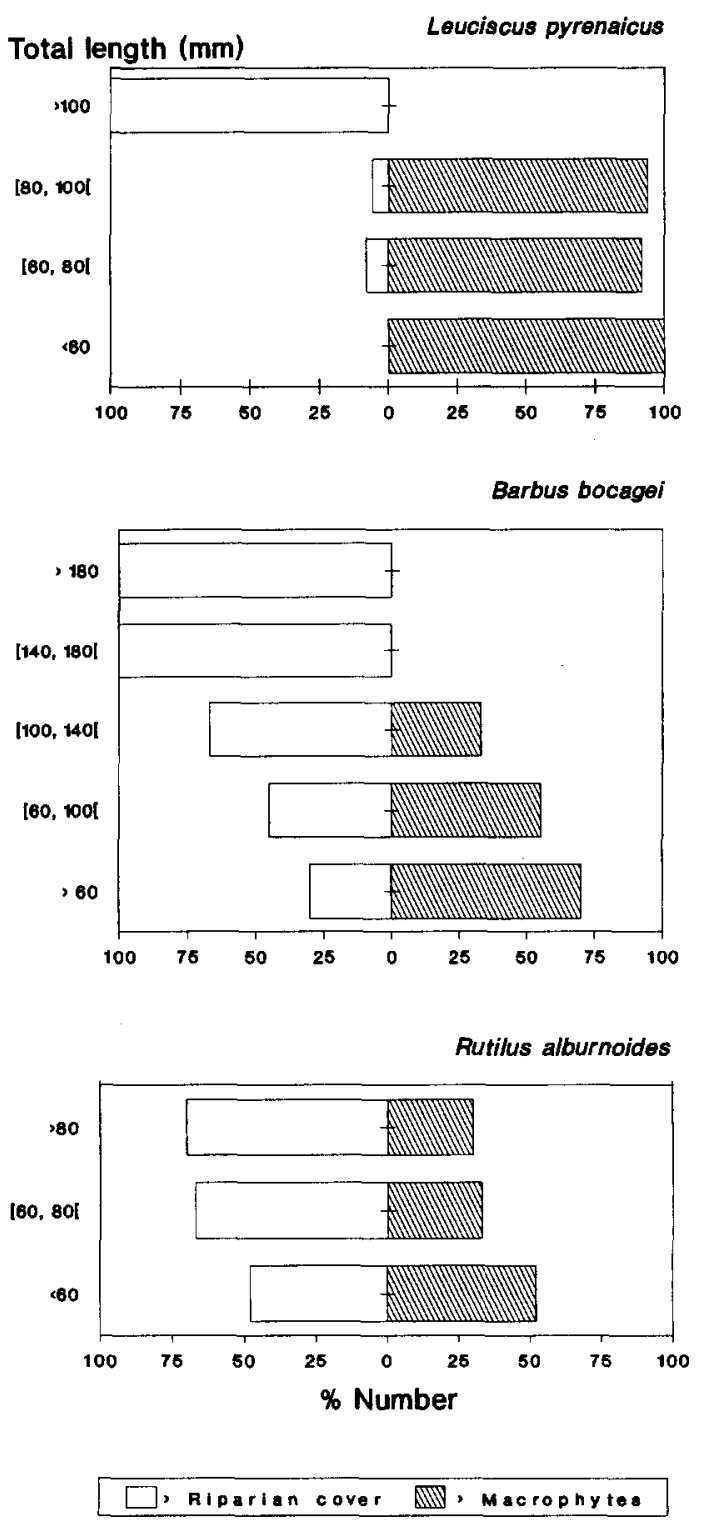

Fig. 4. Distribution of roach, barbel and chub along river banks, in site $\mathrm{E}$. 
$(H=3.938, p<0.05)$ and bank slope $(H=3.938$, $p<0.05)$. Barbel and chub showed a trend for size-class segregation. Small fish $(<100 \mathrm{~mm})$ of both species were found mainly in the shallowest bank, presenting the highest slope and macrophyte cover. Large fish were mainly found in the deepest bank, with a high riparian cover. Small and large roach were found in both banks.

Altogether the gut contents of 105 roach and 103 chub were analysed, yielding a total of 12 and 15 food categories (Table 3). Plant material, including both vascular plant parts, algae and seeds occurred more often in chub diet $(35.9 \%)$ than in roach diet $(23.8 \%)$. Among animal prey, opposite patterns of consumption were found for ephemeropteran nymphs and dipteran larvae, the former being the major prey for chub $(56.8 \%)$ whereas the latter were the major prey for roach $(71.2 \%)$. Terrestrial insects (dipteran adults and Formicidae) accounted for $3.7 \%$ and $7.4 \%$ of total animal prey for roach and chub respectively.

The percentage occurrence of plant material in the diets of fish from distinct sites is presented in Fig. 5. Plant material had an overall major im-

Table 3. Percentage occurrence of plant material and numeric percentage of animal prey in the diets of roach and chub, over all sampling sites.

\begin{tabular}{lcc}
\hline & Roach & Chub \\
\hline Sample size & 105 & 103 \\
Prey number & 646 & 416 \\
\hline Plant material & 23.8 & 35.9 \\
\hline Mollusca & - & 0.5 \\
Athyaephira sp. & - & 1.4 \\
Baetidae nymphs & 8.0 & 22.4 \\
Other Ephemeroptera & 15.8 & 34.4 \\
Odonata nymphs & 0.5 & 1.4 \\
Chironomidae larvae & 50.5 & 17.8 \\
Simulidae larvae & 14.7 & 6.2 \\
Dipteran nymphs & 1.4 & - \\
Dipteran adults & 1.5 & 4.8 \\
Heteroptera & 3.9 & 3.8 \\
Coleopteran adults & 0.6 & 1.4 \\
Hydropsychidae larvae & 0.9 & 0.3 \\
Formicidae & 2.2 & 2.4 \\
Lepidoptera larvae & - & 0.3 \\
Teleostei & - & 2.9 \\
\hline
\end{tabular}

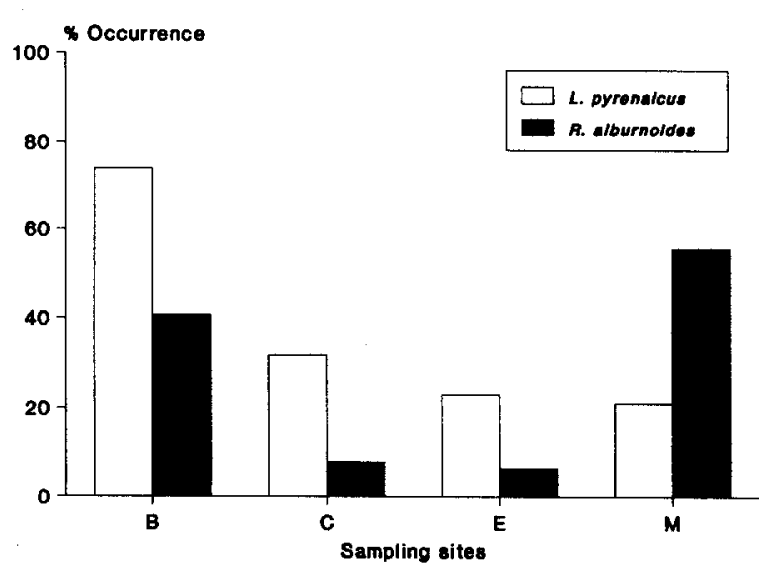

Fig. 5. Spatial variation of the percentage occurrence of plant material in the diets of roach and chub. Sampling site codes as in Fig. 1.

portance in fish diets in site B and M. However, opposite patterns of plant consumption by chub and roach were found at these sites. At site B, plant material was more frequent in the diet of

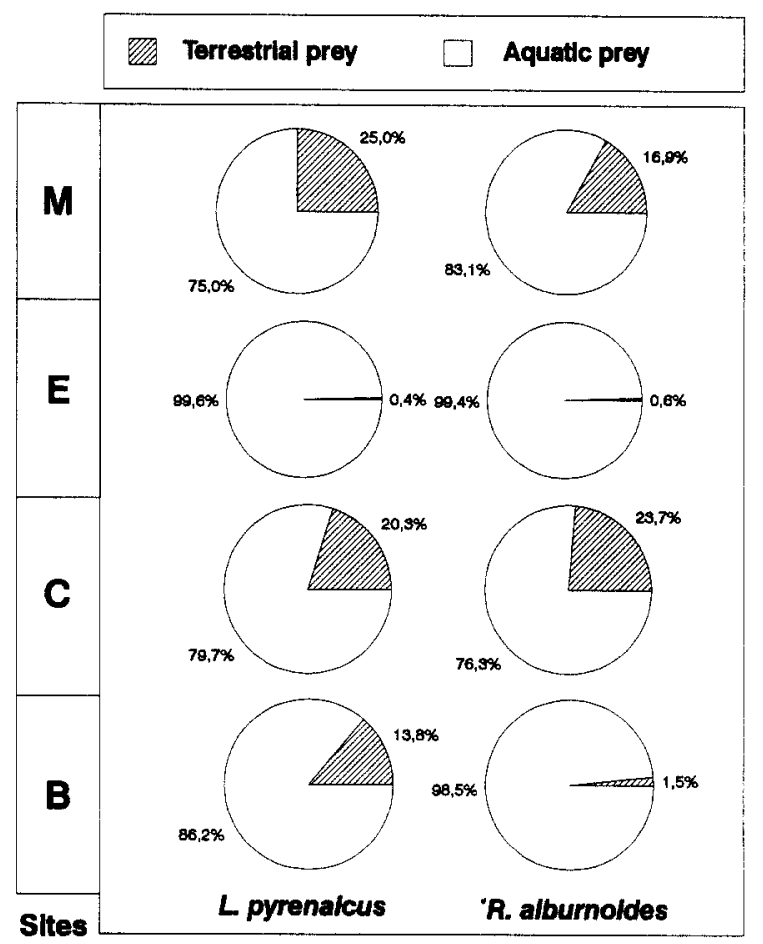

Fig. 6. Spatial variation of the percent composition of terrestrial and aquatic prey in the diets of roach and chub. Sampling site codes as in Fig. 1. 
Table 4. Prey overlap between roach and chub at the different sampling sites, considering only aquatic prey and both aquatic and terrestrial prey. Sampling site codes as in Fig. 1.

\begin{tabular}{lllll}
\hline & \multicolumn{4}{l}{ Sampling sites } \\
\cline { 2 - 5 } & $\mathrm{B}$ & $\mathrm{C}$ & $\mathrm{E}$ & $\mathrm{M}$ \\
\hline Total prey & 0.664 & 0.658 & 0.602 & 0.369 \\
Aquatic prey & 0.714 & 0.686 & 0.602 & 0.408 \\
\hline
\end{tabular}

chub, whereas in site $\mathbf{M}$ it was more frequent in roach diet.

Spatial fluctuations in the importance of animal prey were assessed by combining prey into two categories, terrestrial and aquatic (Fig. 6). Terrestrial prey did not occur in fish diets at site $\mathrm{E}$. Conversely, this category represented more than $10.0 \%$ of total numbers of prey for both chub and roach, at sites $M$ and $C$. At site $B$, terrestrial prey was consumed mainly by chub, but was of low importance in roach diet.

Prey overlaps between roach and chub were high at sites $\mathrm{B}$ to $\mathrm{E}$, but dropped considerably at site $M$ (Table 4). Irrespective of the sampling site, prey-use overlaps were not significantly increased by the exclusion of terrestrial prey from the calculations.

The analysis of chub linear growth revealed no significant spatial differences for the back-calculated lengths of fish at any age $(F=0.655$ for age $1^{+}, F=0.331$ for age $2^{+}$and $F=1.149$ for age $3^{+}$). However, it should be emphasized that for all age groups the smallest fish were found at site A. Conversely, significant spatial differences were obtained for the condition factor for fish between 60 to $80 \mathrm{~mm}(H=8.855, p<0.05)$ and for fish between 80 to $100 \mathrm{~mm}(H=10.300$, $p<0.01$ ). Both size-classes had the highest condition at site $B$.

\section{Discussion}

Habitat structure greatly affected the composition and size-structure of fish assemblages. Riparian and macrophyte cover, bank slope and depth were among the most important variables affecting fish distribution. In general, small barbel, chub and roach favoured shallow areas with high macrophyte cover and bank slope, whereas large barbel and chub dominated in deep areas with a high riparian cover.

The factors leading to such habitat preferences were not investigated but would likely include physical stresses, food availability, predation-risk or competitive interactions (e.g. Schlosser, 1991). Previous studies addressing the relationships among fish and plants have shown that vegetation increases structural habitat complexity, improves invertebrate production and affects fish predatorprey interactions (in Blain \& Boltz, 1992).

Terrestrial insects were minor components of the diet of both roach and chub. Irrespective of the sampling sites, fish fed mainly on plant material and aquatic prey. As no direct estimates of terrestrial invertebrates are available it is unclear whether the low consumption of terrestrial insects by fish was related to low inputs from the riparian zone or to high availability of alternative prey. Inputs of allochthonous material to temperate streams are highly seasonal, with maxima in spring and autumn (Mason \& MacDonald, 1982; Garman, 1991). However, terrestrial prey is consumed by fish mainly in the summer when aquatic invertebrates are in comparatively short supply (Garman, 1991). Spatial variations in the intake of terrestrial insects by fish may also be related to changes in their availability due to differences in the type of tree canopies among sampling sites. According to Mason \& MacDonald (1982), ash trees are poor in insects, in spite of their light canopy, whereas alders provide much larger inputs of invertebrates to streams. Moreover, other factors such as stream hydraulics may also be responsible for heterogeneous spatial distribution of terrestrial invertebrates (in Garman, 1991).

The present study is only an early step towards the assessment of the role played by riparian zones over the population and community dynamics of Iberian stream fish. Future studies should focus on the effects of temporal environmental heterogeneity on fish assemblages. It is expected that in a long-term perspective, the functional interactions of landscape elements on fish 
and the ecological consequences of riparian zone management will be fully evaluated. Thus, the definition of correct options for their conservation/restoration will allow the maintenance of the biodiversity of Iberian aquatic systems.

\section{Acknowledgements}

Thanks are specially due to J.A. Rodrigues, M. J. Alves, R. M. Brito, M. F. Fino and J. L. Costa for their collaboration in field work. This research project (PEA/115/92) is funded by the Junta Nacional da Investigaçao Cientifica (Portugal).

\section{References}

Bain, M. B. \& S. E. Boltz, 1992. Effect of aquatic plant control on the microdistribution and population characteristics of largemouth bass. Trans. am. Fish. Soc. 121: 94-103.

Collares-Pereira, M. J., 1989. Hybridization in european cyprinids: evolutionary potential of unisexual populations. In R. M. Dawley \& J. P. Bogart (eds), Evolution and ecology of unisexual vertebrates, Bull. 466, New York State Museum, Albany, New York: 281-288.

Ferreira, M. T., 1992. Estrutura e dinâmica das comunidades de macrofitos loticos da Bacia Hidrográfica do Sorraia. PhD Thesis, ISA, Univ. Técnica de Lisboa, Lisboa.

Ferreira, M. T. \& I. Moreira, 1987. Distribution patterns of aquatic vegetation in Sor river system, central Portugal. Simp. Intern. Botanica, Lérida.

Francis, R. I., 1990. Back-calculations of fish length: a critical review. J. Fish Biol. 36: 883-902.

Garman, G. C., 1991. Use of terrestrial arthropod prey by a stream-dwelling cyprinid fish. Envir. Biol. Fishes 30: 325331.

Gorman, O. T. \& J. R. Karr, 1978. Habitat structure and stream fish communities. Ecology 59: 507-515.

Green, R. H. \& G. L. Vascotto, 1978. A method for the analysis of environmental factors controlling patterns of species composition in aquatic communities. Wat. Res. 12: 583590.
Hyslop, E. J., 1980. Stomach content analysis - a review of methods and their application. J. Fish Biol. 17: 411-429.

Magalhāes, M. F., 1992. Feeding ecology of the iberian cyprinid Barbus bocagei Steindachner, 1865 in a lowland river. J. Fish Biol. 40: 123-133.

Magalhāes, M. F., 1993. Effects of season and body-size in the distribution and diet of the Iberian chub Leuciscus pyrenaicus (Gunther) in a lowland catchment. J. Fish Biol. 42: 875-888.

Magalhāes, M. F. \& M. J. Collares-Pereira, 1991. Food resources partitioning within an iberian stream cyprinid assemblage. 7th Int. Ichth. Congr., Abstract: 45.

Magalhāes, M. F., M. J. Collares-Pereira \& M. M. Coelho, 1991. Spatial and temporal patterns of distribution and abundance of cyprinids in a portuguese lowland system. 7 th Int. Ichth. Congr., Abstract: 45.

Mason, C. F. \& S. M. Macdonald, 1982. The input of terrestrial invertebrates from tree canopies to a stream. Freshwat. Biol. 12: 305-311.

Rahel, F. J. \& W. A. Hubert 1991. Fish assemblages and habitat gradients in a Rocky-Mountain-Great Plains stream: biotic zonation and additive patterns of community change. Trans. am. Fish. Soc. 120: 319-332.

Rustarazo, M. M., E. B. Colebras \& D. Garcia de Jalon, 1989. Estudio de las poblaciones del barbo Barbus bocagei Stein., 1865) del Rio Jarama. Actas Col. Luso-esp. Ecol. Bacias Hidrog. Rec. Zool., 277-286.

Schiemer, F. \& M. Zalewski, 1992. The importance of riparian ecotones for diversity and productivity of riverine fish communities. Neth. J. of Zool. 42: 323-335.

Schlosser, I. J., 1987. A conceptual framework for fish communities in small warmwater streams. In W. J. Matthews \& D. C. Heins (eds), Ecology and Evolution of North American stream fishes. Univ. Oklahoma Press, Norman: 17-24.

Schlosser, I. J., 1991. Stream fish ecology: a landscape perspective. BioScience 41: 704-712.

Wallace, R. K., 1980. An assessment of diet overlap indexes. Trans. am. Fish. Soc. 110: 72-76.

Zalewski, M., 1990. The ecotone concept in conservation and fisheries management of riverine ecosystems. Proc. Unesco/ Mab Int. Seminar: 80-94.

Zalewski, M., 1991. Review of the session: rivers. In M. Zalewski, J. E. Thorpe \& P. Gaudin (eds), Role of land/ inland water ecotones in landscape management and restoration, Lodz: Unesco, 17-20. 